\title{
Pursuing Frugal Innovation for Sustainability at the Grassroots Level
}

\author{
Mokter Hossain, ${ }^{1} \odot$ Jarkko Levänen, ${ }^{2}$ \\ and Marleen Wierenga ${ }^{3}$ \\ 'Qatar University, Qatar, ${ }^{2}$ Lappeenranta-Lahti University of Technology LUT, Finland, and \\ ${ }^{3}$ Aalto University, Finland
}

ABSTRACT Firms are often criticized for their reluctance to embrace sustainability in their business strategies. Frugal innovation is a recent concept that represents a new way for firms to serve underserved customers in developing countries while also promoting sustainability. Based on three cases of frugal innovation at the grassroots level in India, this article demonstrates how frugal innovation presents a promising way to tackle some of today's pressing societal problems with new business models. We use a range of parameters for economic, social, and environmental sustainability to strengthen the case for frugal innovation. This article attempts to inspire scholars to consider frugal innovation further in their future research endeavors and encourage firms to integrate it into their existing business models.

KEYWORDS business model, emerging markets, entrepreneurship, frugal innovation, grassroots innovation, sustainability

AGCEPTED BY Guest Editors Oli Mihalache and Henk Volberda

\section{INTRODUCTION}

Frugal innovation is a relatively recent concept that represents a new way to serve traditionally underserved customers without compromising sustainability. A lack of external resources traditionally constrains firms from accomplishing their goals, but some firms manage to transform this limitation into an opportunity. Through frugal innovations, firms reduce the use of resources that may be scarce or expensive locally in order to develop profitable solutions at an affordable price while eliminating the need for any external infrastructure (Asakawa, Cuervo-Cazurra, \& Un, 2019). Frugal innovations are often developed by large multinational firms for emerging markets (Zeschky, Widenmayer, \& Gassmann,

Corresponding author: Mokter Hossain (mokter@qu.edu.qa)

(C) The Author(s), 2021. Published by Cambridge University Press on behalf of The International Association for Chinese Management Research. This is an Open Access article, distributed under the terms of the Creative 
Table 1. An overview of the three cases

\begin{tabular}{lccc}
\hline \hline Features & MittiCool & Ksheera & Fayashree \\
\hline Product & Clay potteries & Milking machine & Sanitary pad making machine \\
Founder origin & Gujarat, India & Karnataka, India & Tamil Nadu, India \\
Target customers & Households & Farmers & Social enterprises \\
Founded & 1988 & 1999 & 2004 \\
Employees $(\#)$ & 50 & 25 & 10 \\
\hline \hline
\end{tabular}

2011), but they can also be developed in resource-scarce environments by individuals (Hossain, 2017). This article focuses on the latter group, where frugal innovations are developed at the grassroots level.

Frugal innovations can also drive sustainable development. As the concept emphasizes using fewer resources to develop sustainable products that are affordable and accessible, especially for low-income customers, the link between frugal innovation and sustainability is well proven (Albert, 2019). Evidence is emerging to support sustainability as a key outcome of frugal innovation (Hossain, 2020). Furthermore, scholars are converging on the view that frugal products can be affordable for low-income customers without sacrificing sustainability aspects (Levänen et al., 2016). Based on three cases of Indian firms, this article shows how firms apply frugal innovation to serve low-income customers in developing countries. The findings show that grassroots firms can develop frugal products to meet the needs of underserved customers in a sustainable way.

\section{THE THREE GASES}

Frugal innovations are emerging in various corners of the developing world, especially in Asia and Africa. India is considered a particular hotbed of frugal innovation. We, therefore, consider three widely discussed cases that originated at the grassroots level in India, namely MittiCool, Ksheera Enterprises, and Jayashree Industries (Table 1). To describe and analyze these cases, we use data from interviews conducted with key persons within these firms. We also collected information from newspapers, reports, firms' websites, and video clips.

\section{MittiCool}

MittiCool is a small enterprise that makes clay pottery products. The entrepreneur behind the firm is Mansukhbhai Prajapati from Gujarat State. He grew up within a pottery-making family, and he dropped out of school to work and help support his family. MittiCool's flagship product is a fridge made of clay. After working for many years making basic pottery items, Prajapati began to work on more innovative products. Made from terracotta clay, the Mitticool fridge can be used for 
storing perishables like milk, fruits, and vegetables. It works by cooling through evaporation, so it does not need electricity. The struggles and repeated failures of the firm over the years have been widely covered in the local, national, and global media, including the BBC and Discovery Channel. Prajapati has also spoken at TED after a Worldwide Talent Search. MittiCool's products have trickled-up to more developed countries, such as France and Singapore. The enterprise also produces about a hundred other clay-based products, such as water bottles, tableware, and pressure cookers. Aesthetically improving traditional clay products has been a key achievement in modernizing these old-fashioned products.

\section{Ksheera Enterprises}

Ksheera Enterprises manufactures low-cost milking machines, invented by Raghava Gowda, under the brand names Milkmaster and Imilker. Gowda is a farmer and a retired schoolteacher, and he invented the machine based on his experiences milking his cows by hand, which was time consuming, uncomfortable, and led to udder infections due to lack of appropriate hygiene. Gowda, therefore, wanted to develop a milking machine that would be affordable for farmers with one to several cows, those who would be unable to afford the conventional, expensive high-capacity machines. Inspired by the gutter spray pump used to spray insecticides, he invented a small, hygienic, and ergonomic low-cost milking machine that could be operated both with and without electricity. It took four years to develop a functional machine that could milk 1.5-2.0 liters per minute. Over 12,000 machines have been sold across India and other countries, including Sweden, New Zealand, Mexico, and Kenya.

\section{Jayashree Industries}

Arunachalam Muruganantham, who first invented a low-cost sanitary napkin and then a machine to make them, established Jayashree Industries. After witnessing his wife's use of dirty cloths during menstruation, he learned that women in rural India typically use ashes, old newspapers, sand husks, and dried leaves to absorb menstruation bleeding rather than buying expensive napkins from international brands. Women often need to prioritize buying essential items for their families over sanitary napkins for themselves, so Muruganantham's inventions offer an affordable solution to the unhygienic practices employed by women in rural India. Muruganantham aims to make the use of sanitary napkins universal in India, compared to only a $2 \%$ rate of use in rural areas now. The machine comes in manually operated and semi-automatic variants costing US $\$ 2,000$ and US $\$ 3,500$, respectively. The machines are typically sold to females who then start a social enterprise based on using the machine to make and sell sanitary napkins for their communities. 


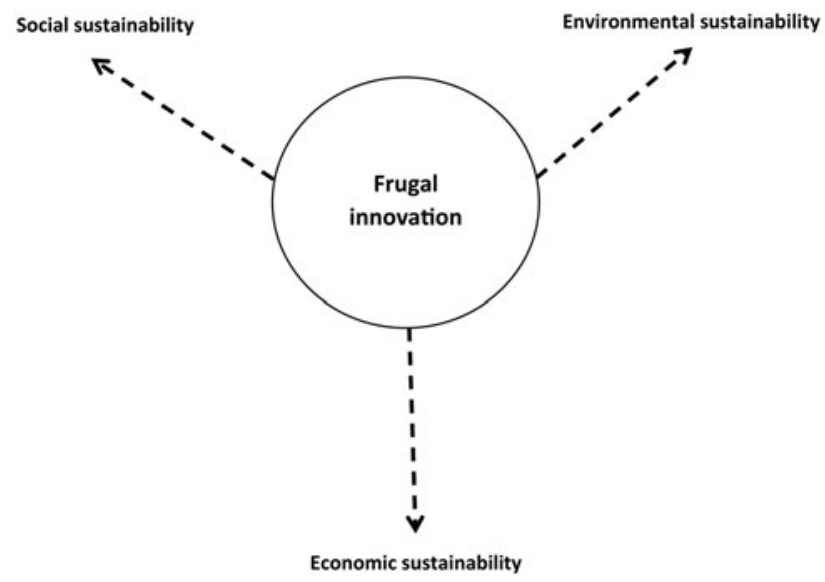

Figure 1. Frugal innovation at the intersection of three sustainability aspects

\section{APPROACH TO ASSESSING THE SUSTAINABILITY OF THE GASES}

Sustainability is of great interest to scholars, managers, and policymakers. The concept of sustainability can be defined as development that does not sacrifice the needs of future generations and which causes minimal harm to people and the environment. Using a range of parameters for the three pillars of sustainability, we demonstrate the importance of frugality and show how frugal innovation can serve low-income customers in developing countries while embracing sustainability (Figure 1). Serving underserved customers without sacrificing sustainability can be an interesting opportunity for firms, so we will demonstrate the relationship between frugal innovation and sustainability.

The economic aspect of sustainability includes, for example, access to decent employment and the ability to improve one's living standards. The social aspect, meanwhile, comprises respect for human rights and fair inclusion in societal development. Finally, the environmental aspect considers the sustainable use of natural resources and the prevention of pollution.

\section{SUSTAINABILITY ASSESSMENT FOR THE THREE GASES}

Figure 2 shows a snapshot of the outcomes for the three frugal enterprises. The thickness of the arrow reveals that the impact of frugal innovations developed at the grassroots level is stronger in the social and economic aspects than in the environmental aspect. By applying these parameters, we explore the cases of frugal innovation to better understand their sustainability outcomes.

\section{Economic Sustainability}

All three enterprises have created jobs for people who may have otherwise been unemployed. For example, Mitticool has 50 full-time employees and many more 


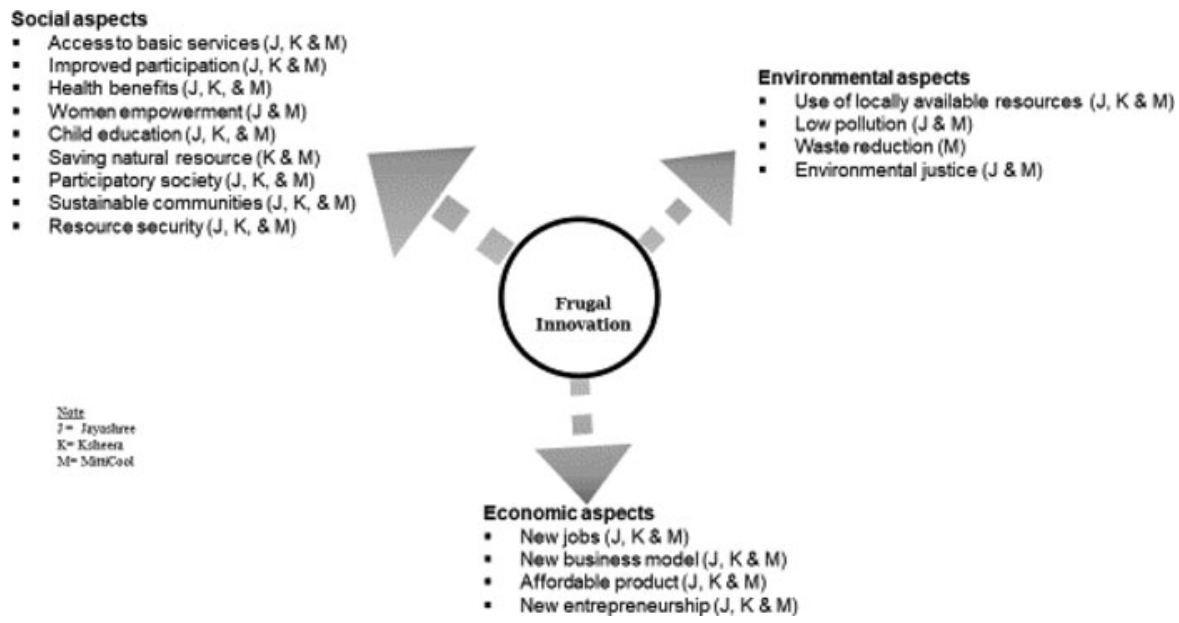

Figure 2. Sustainability outcomes of the three cases

working in transport and delivery activities or as salespeople and dealers. Indeed, MittiCool has a large salesforce, mostly women, who sell its clay products door to door (D2D) in various regions of India. Ksheera, meanwhile, is located in a village with few employment opportunities. The entrepreneur takes pride in employing local youths who would otherwise likely migrate to larger cities in search of employment. The 25 employees can produce 250 machines each month.

Jayashree sells its machines through a business-to-business (B2B) model. Local NGOs and social enterprises purchase the machines and then employ women to produce and sell sanitary napkins locally. Machines have been installed in 27 states across India and in seven other countries, generating over 2,100 jobs for women across India in the process. Considering the stigma related to menstruation, these women sell the sanitary pads directly to customers, including through D2D sales, and educate them on the importance of proper hygiene during menstruation. Throughout the product lifecycle, these firms minimize costs to offer affordable products using simple technologies.

In addition to creating jobs, the three firms offer products to markets that were underserved by existing solutions. They developed new business models for marketing and production that functioned well in the local context and provided access to quality goods. For example, Ksheera sells its products directly to customers and through dealers and online marketplaces. Because one of Gowda's milking machines can still be relatively expensive for a smallholder, the firm developed a sharing model that allows more of them to automate their milking processes. The creation of these new enterprises has clearly provided an important local economic boost. Within India, the Mitticool products are available in over 200 outlets in 63 cities and nine states. It is important to also note, however, that businesses based on frugal-innovation may also create new entrepreneurial opportunities, as the example of Jayashree shows. 


\section{Social Sustainability}

Businesses based on frugal innovation may also have social implications, as the studied cases show. The affordable pricing of their products increases people's access to basic services that may have previously been unattainable. Having access to these services strengthens feelings of participation in society and enhances living standards for those living on a limited budget. The studied businesses also bring health benefits in terms of improved hygiene or better air quality, because in areas where the electricity supply is unreliable, people may use alternatives such as diesel generators. For example, the Mitticool fridge does not need electricity, so there is no need for a diesel generator to preserve food. This leads to better air quality because diesel generators release harmful particles, and not needing to buy diesel leads to lower daily household expenses. Mitticool also advocates the use of products made from organic materials, Ksheera promotes a hygienic way of milking cows, and Jayashree enables hygienic menstrual care. The firms empower local citizens, especially women, as an underprivileged group.

In reaction to local poverty, Mitticool is funding the schooling of some children in its village through some of the profits it is generating. Prajapati knows from personal experience that in families with a constrained budget, it is difficult to complete a full education because children need to support the family by working, so he started this initiative, and to not leave the families indebted, Prajapati does it in secret. The solution provided by Jayashree helps to employ women, which provides them with a source of income but also gives them self-confidence and empowerment. It also increases the overall income in a household, which may mean, for example, better and longer education for children. The ergonomic improvements provided by the milking machine show the social implications of frugal innovations. Even though Ksheera's milking machine is manually powered, it is much easier than milking by hand.

Most importantly, studied innovations were developed by people who themselves experienced poverty and resource-scarcity, so these frugal innovations are also strong in terms of inclusion. Their innovations meet the real needs of local communities. Gowda suffered because he did not have access to an affordable milking machine. The clay fridge and the machine for making sanitary napkins are responses to needs in the broader community, namely to preserve food and have access to affordable feminine hygiene products. Their achievements are also reflected in the awards given to the entrepreneurs: The MittiCool fridge has received over 90 awards, while Forbes Magazine described Mansukhbhai Prajapati as 'India's most powerful rural entrepreneur', and his milking machine received a national award from the then president of India. Muruganantham, meanwhile, was recognized as one of Time Magazine's 100 Most Influential People in the World for his invention, and in 2016, he received the Padma Shri, the fourth-highest civilian award in the Republic of India, for social work. 


\section{Environmental Sustainability}

From an environmental perspective, the firms use locally available raw materials, such as clay or recycled metals, in their products. Local availability reduces the need for transportation and hence lowers emissions, but it also strengthens the local ecosystem and provides more sustainable opportunities in the supply chain. Using re-used materials in production also offsets waste generation in line with the notion of a circular economy. As they come from resource-scarce environments, the case firms demonstrate that recycling is an integral part of their business models. All three firms promote awareness of using environmentally friendly products.

Many of the products work manually and do not require electricity, so they do not create emissions in the operational phase of their life cycles. Indeed, the claybased fridge uses the natural cooling effect of evaporation to keep its contents cool. Even though powered models also exist, the manually operated milking machine is still more efficient than milking by hand. Similarly, the machine for making sanitary napkins is also manually operated, so production is not dependent on the availability of electricity.

\section{GONGLUSION}

With these three cases, we have demonstrated that frugal innovations can address sustainability challenges in multiple ways with business models. The evidence is stronger when grassroots actors experience resource-scarcities themselves while developing frugal innovations. A key advantage for entrepreneurs at the grassroots level is their comprehensive understanding of local conditions when coming up with appropriate solutions. It is clear from the three cases that frugal innovation plays a greater role in the social and economic aspects than in the environmental aspect. However, frugal innovation can still play a very significant role in the environmental aspect, too (Figure 2). As many challenges related to frugal innovations at the grassroots level remain unaddressed, we hope this study will inspire other researchers to explore frugal innovation and its association with sustainability in the future.

\section{REFERENGES}

Asakawa, K., Guervo-Cazurra, A., \& Un, C. A. 2019. Frugality-based advantage. Long Range Planning, 52(4): 101879.

Hossain, M. 2017. Mapping the frugal innovation phenomenon. Technology in Society, 51: 199 208.

Hossain, M. 2020. Frugal innovation: Conception, development, diffusion, and outcome. Journal of Cleaner Production, 262: 121456.

Levänen, J., Hossain, M., Lyytinen, T., Hyvärinen, A., Numminen, S., \& Halme, M. 2016. Implications of frugal innovations on sustainable development: Evaluating water and energy innovations. Sustainability, 8(1): 1-17

(C) The Author(s), 2021. Published by Cambridge University Press on behalf of The International Association for Chinese Management Research 
Zeschky, M., Widenmayer, B., \& Gassmann, O. 2011. Frugal innovations in emerging markets. Research-Technology Management, 54(4): 38-45.

Mokter Hossain (mokter@qu.edu.qa) is an Assistant Professor at the Center for Entrepreneurship, College of Business and Economics, Qatar University. Previously, he worked at Manchester University, Aalborg University, Aalto University, and Imperial College London. He has a PhD in strategy and venturing, an MBA in International Business, an MBA in Marketing, and a Postgraduate Diploma in Finance. His research interests lie at the intersection of entrepreneurship, innovation, and strategy on topics such as frugal innovation, open innovation, crowdsourcing, crowdfunding, sharing economy, etc.

Jarkko Levänen (jarkko.levanen@lut.fi) is an Assistant Professor of Sustainability Science at LUT University, Finland. His research focuses on new socio-ecological models and sustainability management in the areas of circular economy and climate change mitigation. Jarkko's interests include sectoral transitions, new business models, innovation processes, and novel policy approaches in various socio-economic and cultural contexts.

Marleen Wierenga (marleen.wierenga@aalto.fi) is a Postdoctoral Researcher at the Aalto University School of Business, Finland. Her research interests are in the area of entrepreneurship, innovation, and poverty. More specifically, Marleen is interested in understanding entrepreneurial approaches of different organizations in different contexts to solving poverty and related problems. Marleen completed her $\mathrm{PhD}$ on innovative entrepreneurship in the low-income context at the Aalto University in 2020, and currently, she is studying impact investing in the Nordics.

Manuscript received: March 22, 2018

Final version accepted: July 13, 2020 (number of revisions - 3) 